[研究速報]

\title{
マニピュレータの障害物回避動作計画を 考慮した凸多面体間の干渉チェック法
}

\author{
湯 浅 秀 男* 伊藤 正 美*
}

\begin{abstract}
マニピニレータの障害物回避動作を決定するためには，マニピュレータ・リンクと障害物との干渉チェックを する必要がある.これまでは, 主にいろいろな制約を設けてチェックを容易にしてきたが, 本稿はなるへく一般 的で，かつ計算の単純な干渉チェック法を提案する、マニピニレータ・リンク及び障害物は，凸多面体またはそ の組合せで表現し，それらの面と頂点の位置関係のみを用いて，干渉するための必要十分条件を比較的単純な関 数を用いて表す.

さらにこの関数は，Denavit 等の表記法を用いれば，容易に関節変数ベクトルの関数となり，千渉チェックが 関節空間でできるため，マニピュレータの障害物回避動作計画に適用できる.
\end{abstract}

\section{1. は じめに}

マニピュレータの動作計画を行う際, 解決しておかな ければならない重要な問題の一つに, マニピュレータの 障害物回避動作の決定問題 ${ }^{1)}$ がある それにはまず, 障 害物とマニピュレータ・リンクとの干涉をチェックする 必要がある. 今までは，作業空間を二次元に限定する方 法2), 障害物やリンクを立方体, 円柱などで近似する方 法 $^{3}$, 運動を回転運動のみの場合や並進運動のみの場合 に分けて考学る方法4), 干涉しない十分条件のみを求め, その繰り返しにより必要条件に近づける方法), 関節角 度空間を量子化する方法卢， シンプレックス法を用いる 方法7などにより解決をはかってきた。

しかし，なるべく一般的な場合の干渉条件が，マニピ ニレータの障害物回避動作計画に使いやすい関数形で表 すとどのよらになるかを考察することは重要なことであ る. そこで本稿では, 障害物やマニピニレータ・リンク を凸多面体またはその組合せで表現し，比較的単純な関 数息を用いて凸多面体どうしが干涉しないための必要十 分条件を示す. さらにその関数は, 凸多面体の面と頂点 との位㯰関係のみから導かれているので, Denavit 等の 表記法"きをとのま使用することが可能である. そのた め, マニピュレータを点として扱える関節空間（関節変 数から成る空間) での干渉チェック関数に容易に変換で きることも示す。

原稿受付 1986 年 12 月 18 日

* 名古屋大学工学部情報工学科

日本ロポット学会誌 5 巻 4 号

\section{2. 障害物とマニピュレータの表現}

障害物及びマニピュレータの各リンクは, 凸多面体ま たはその組合せで表現され、マニピュレータは回転関節 と直動関節から成るリンク数が $の$ のニピュレータと仮 定する (Fig. 1). この仮定により，凸多面体の表現法を 明確にすれば，障害物及びマニピュレータ・リンクの表 現法を明確にしたことになる.凸多面体の組合せで表現 される場合は, 複数の凸多面体の障害物, 複数の凸多面 体から成るリンクと考えれば良いので，以下では議論を 簡単にするために，障害物及びマニピュレータの各リン クは一つの凸多面体で表現されるものとする.

凸多面体は，その面をすべて記述することによって表 現できる. 平面は, 斉次座標表現を用いると四次元行べ クトルとして,
Convex polyhedric obstacle

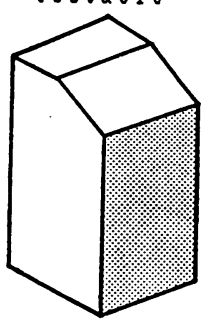

$\mathrm{n}-\mathrm{link}$

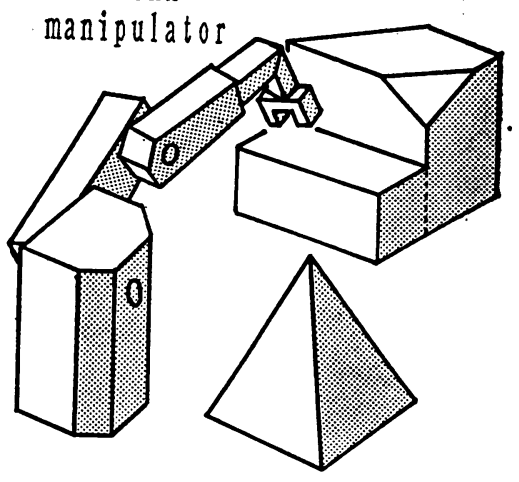

Fig. 1 Obstacles and a manipulator in a workspace 


$$
\begin{gathered}
\boldsymbol{f}=(a, b, c, d) \\
\text { たたし, } \quad a^{2}+b^{2}+c^{2}=1
\end{gathered}
$$

湯浅秀男

と表現される．ここで, $(a, b, c)^{\prime}$ はその平面の外向き 法線ベクトルであり， $d$ は, 絶対値が原点とその平面と の距離，符号が原点からその平面に下ろした垂線ベクト ルと外向き法線ベクルとの内積の反対の符号である.

斉次座標表現では，点はスケール因子“1”を加えた 四次元列ベクトルで,

$$
v=(x, y, z, 1)^{\prime}
$$

と表現される.

点と平面の位置関係は，両者の内積をとればわかる。 $\boldsymbol{f} \cdot \boldsymbol{v}>0$ の時, 点 $\boldsymbol{v}$ は平面 $\boldsymbol{f}$ の外側にあり, $\boldsymbol{f} \cdot \boldsymbol{v}<0$ の 時内側, $\boldsymbol{f} \cdot \boldsymbol{v}=0$ の時平面上にある. 従って, 凸 $L$ 面体 $p$ に含まれる点の集合 $P$ は，第 $i$ 面を $f_{i}$ とすると，

$$
P=\bigcap_{i=1}^{L}\left\{v: f_{i} \cdot v \leqq 0\right\}
$$

と表現できる.こうすると, 凸多面体の各面の外向き法 線ベクトルは対応する $\boldsymbol{f}_{\imath}$ の外向き法線ベクトルに一致 する．集合 $P$ を交わりを用いずに表現するために,

$$
q_{p}(\boldsymbol{v})=\max _{i}\left\{\boldsymbol{f}_{\imath} \cdot \boldsymbol{v}\right\}
$$

を定義する，すると $P$ は,

$$
P=\left\{v: q_{p}(\boldsymbol{v}) \leqq 0\right\}
$$

と表されるので, $q_{p}(\boldsymbol{v})$ は $P$ を表す関数といえる.

このよらに関数表現にしておくと， $t$ をパラメータと して経路 $v(t)$ が与えられた時, $q_{p}(v(t))$ を計算するこ とにより, 経路全体にわたる干渉チェックが容易に定式 化できる. 従って, グローバルな経路を計画することが 可能となる.

\section{3.凸多面体どうしの干渉チェック}

\section{1 干涉の分類}

凸多面体どうしの干渉は，広義に考えるとつぎの二通 りに分けられる.

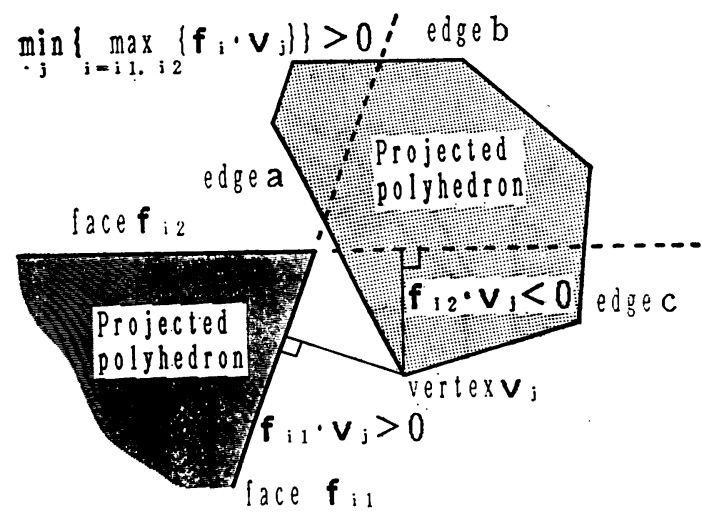

Fig. 2 Collision free configuration
伊藤 正美

（1）一方の頂点と他方の面との干渉.

(2) 両方の稜どうしでの干渉.

（1）の場合の干啮チェックは，一方の凸多面体の頂点 が他方の凸多面体の面に対してどのような位置にあるか を判断することにより行う．つまり，一つの頂点でも他 方の凸多面体の内部にあれば干渉しており，すべての頂 点が他方の凸多面体の或る一つの面を無限に広げた平面 の外側にあれば干涉していないと判断できる.

(2)の場合は, 両方の凸多面体の稜どうしの組合せに 対して，お互いが食い込んでいるかどらかを判断するこ とによって，千渉チェックを行う.

この二つの場合で干渉がすべてチェックできることを, 以下に順をおって示す．すなわち，それぞれの場合につ いて干涉しないための十分条件を関数の形で求め，それ らを組合せることにより，凸多面体どうしが千涉しない ための十分条件を求める.ささらに，それが必要十分条件 であることを証明する. なお以下では, 頂点, 稜, 面の 接触》)は干涉の一部として処理する.

3.2 一方の頂点と, 他方の面との干涉チェック

凸多面体 $p_{1}$ の面を $\boldsymbol{f}_{1}, \boldsymbol{f}_{2}, \cdots, \boldsymbol{f}_{f_{1}}$, 凸多面体 $p_{2}$ の頂点 を $v_{1}, v_{2}, \cdots, v_{v 2}$ とする. たたし， $f_{1}$ は $p_{1}$ の面の数， $v_{\varepsilon}$ は $p_{2}$ の頂点の数である.

これらの位置関係を調べるために，頂点と面のすべて の組合せについてまとめて内積を計算すると，

$$
\begin{aligned}
& {\left[\begin{array}{c}
\boldsymbol{f}_{1} \\
\boldsymbol{f}_{2} \\
\vdots \\
\boldsymbol{f}_{f_{1}}
\end{array}\right]\left(\boldsymbol{v}_{1}, \boldsymbol{v}_{2}, \cdots, \boldsymbol{v}_{v 2}\right)}
\end{aligned}
$$

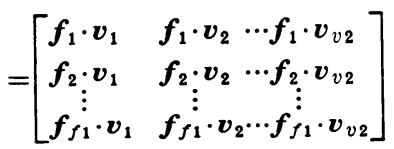

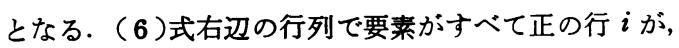
つまり $\min _{j}\left\{f_{i} \cdot v_{j}\right\}>0$ となる行 $i$ があれば, $p_{1}$ の第 $i$ 面に対して $p_{2}$ の頂点がすべて外側にあるから $p_{1}$ と $p_{2}$ は干渉していない. また要素がすべて負の列 $j$ が, つまり $\max _{i}\left\{\boldsymbol{f}_{i} \cdot \boldsymbol{v}_{j}\right\} \leqq 0$ となる列 $j$ があれば， $\boldsymbol{p}_{2}$ の第 $j$ 頂点は $p_{1}$ の内部にあり干涉している. 以上のことを 表す関数として,

$$
\left\{\begin{array}{l}
q_{f}\left(p_{1}, p_{2}\right)=\max _{i}\left\{\min _{j}\left\{\boldsymbol{f}_{i} \cdot \boldsymbol{v}_{j}\right\}\right\} \\
q_{c}\left(p_{1}, p_{2}\right)=\min _{j}\left\{\max _{i}\left\{\boldsymbol{f}_{i} \cdot \boldsymbol{v}_{j}\right\}\right\}
\end{array}\right.
$$

を定義すれば, $p_{1}$ と $p_{2}$ は $q_{f}\left(p_{1}, p_{2}\right)>0$ なら干涉して おらず, $q_{c}\left(p_{1}, p_{2}\right) \leqq 0$ なら干渉している.

$p_{2}$ の面と $p_{1}$ の頂点についても同様の計算を行えば, $q_{f}\left(p_{2}, p_{1}\right)>0$ なら干涉しておらすั, $q_{c}\left(p_{2}, p_{1}\right) \leqq 0$ なら 干涉していることがわかる. 従って, 一方の頂点と他方 


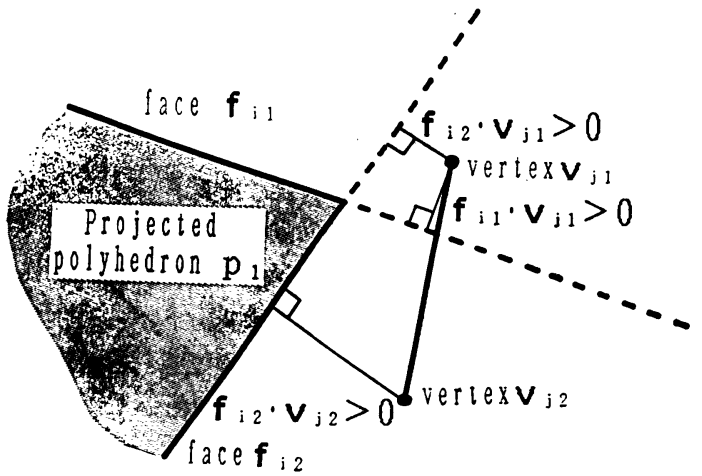

Fig. 3 Collision free configuration (2)

の面とが干渉しないための十分条件は,

$$
\max \left\{q_{f}\left(p_{1}, p_{2}\right), q_{f}\left(p_{2}, p_{1}\right)\right\}>0
$$

となる.

\section{3 两方の凸多面体の稜どうしでの干涉チェック}

凸多面体 $p_{1}$ の稜は, その稜を構成する二面の組 $\left(\boldsymbol{f}_{\imath_{1}}\right.$,

$\left.f_{12}\right)$ で表し, 凸多面体 $p_{2}$ の稜は, その稜の端点である 二頂点の組 $\left(\boldsymbol{v}_{j 1}, \boldsymbol{v}_{j 2}\right)$ で表す．稜どうしでの干渉を考え る場合，二つの凸多面体の向かい合っている稜どうしを 考えれば十分である. 稜 $\left(\boldsymbol{f}_{i_{1}}, \boldsymbol{f}_{i_{2}}\right)$ が $p_{2}$ に向いている とは, $p_{2}$ のすべての頂点が $\boldsymbol{f}_{\imath_{1}}$ または $\boldsymbol{f}_{\imath_{2}}$ の外側にあ ることと考えられる (Fig.2). これを(6)式右辺の行列 の要素を用いて表現すると,

$$
\min _{j}\left\{\max \left\{\boldsymbol{f}_{\imath_{1}} \cdot \boldsymbol{v}_{j}, \boldsymbol{f}_{i_{2}} \cdot \boldsymbol{v}_{j}\right\}\right\}>0
$$

となる. 従って，（8)式を満たす稜 $\left(\boldsymbol{f}_{i_{1}}, \boldsymbol{f}_{\imath_{2}}\right)$ のみで干 渉チェックを行えば十分である.

稜 $\left(\boldsymbol{f}_{\imath 1}, \boldsymbol{f}_{\imath 2}\right)$ と干渉の可能性のある $p_{2}$ の稜は, 無限 に広げた平面 $\boldsymbol{f}_{\imath_{1}}$ または $\boldsymbol{f}_{i 2}$ と必ず交差する（Fig. 2 edge $a \sim c)$. この条件も, 上と同様に( 6 )式右辺の行列 の要素を用いて表現すると,

$$
\left\{\begin{array}{l}
\min \left\{\boldsymbol{f}_{i 1} \cdot \boldsymbol{v}_{j_{1}}, \boldsymbol{f}_{\imath 2} \cdot \boldsymbol{v}_{j_{2}}\right\}>0 \\
\min \left\{\boldsymbol{f}_{\imath_{1}} \cdot \boldsymbol{v}_{\jmath_{2}}, \boldsymbol{f}_{\imath 2} \cdot \boldsymbol{v}_{\jmath_{1}}\right\} \leqq 0
\end{array}\right.
$$

となる。

以上の条件を満たす稜 $\left(f_{\imath 1}, f_{\imath 2}\right),\left(v_{\jmath_{1}}, v_{\jmath_{2}}\right)$ に対し $\tau$,

$$
q_{d}\left(i_{1}, i_{2}, j_{1}, j_{2}\right)=\boldsymbol{f}_{i_{1}} \cdot \boldsymbol{v}_{\jmath_{1}} \times \boldsymbol{f}_{i_{2}} \cdot \boldsymbol{v}_{\jmath_{2}}-\boldsymbol{f}_{i_{1}} \cdot \boldsymbol{v}_{\jmath_{2}} \times \boldsymbol{f}_{i_{2}} \cdot \boldsymbol{v}_{\jmath_{1}}
$$

という関数を定義し，その符号と干渉との関係を調べる. まず，稜 $\left(v_{j 1}, v_{j 2}\right)$ が平面 $\boldsymbol{f}_{\imath 1}, \boldsymbol{f}_{\imath 2}$ のらち, どちら か一方としか交差しない場合，Fig. 3 に示すように交差 しない平面に対して $v_{j 1}, v_{j 2}$ は共に外側にあるので，明 らかに稜 $\left(\boldsymbol{f}_{i 1}, \boldsymbol{f}_{i 2}\right)$ と $\left(\boldsymbol{v}_{j_{1}}, \boldsymbol{v}_{j_{2}}\right)$ との干㗪はない. たこの時, $\boldsymbol{f}_{i_{1}} \cdot \boldsymbol{v}_{j_{2}} \geqq 0$ または $\boldsymbol{f}_{i 2} \cdot \boldsymbol{v}_{j_{1}} \geqq 0$ となり，(9-1), (9-2)式より， $q_{d}\left(i_{1}, i_{2}, j_{1}, j_{2}\right)>0$ となる.

次に, 稜 $\left(v_{j 1}, v_{j_{2}}\right)$ が, 平面 $f_{\imath 1}, f_{\imath 2}$ の両方と交差

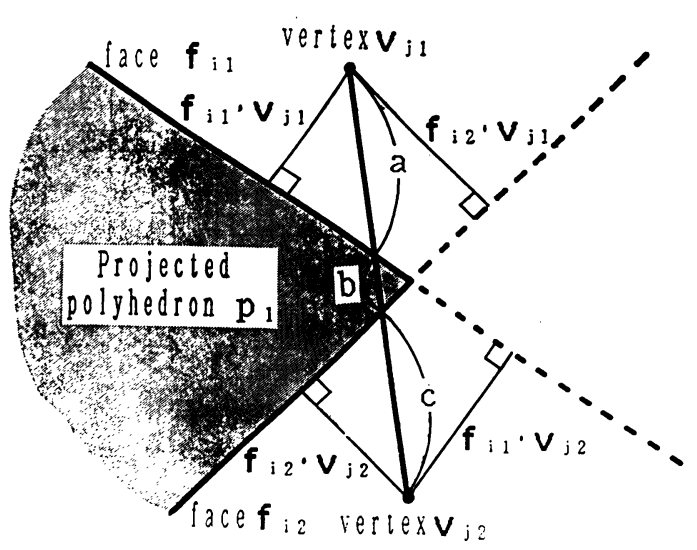

Fig. 4 Collided configuration

した場合を考え, “もし $q_{d}\left(i_{1}, i_{2}, j_{1}, j_{2}\right)>0$ ならば稜 $\left(\boldsymbol{f}_{i_{1}}, \boldsymbol{f}_{i 2}\right)$ と $\left(\boldsymbol{v}_{j_{1}}, \boldsymbol{v}_{j_{2}}\right)$ との干渉はない”ということを 示す. ここでは, その対偶 “稜 $\left(\boldsymbol{f}_{i 1}, \boldsymbol{f}_{\imath_{2}}\right)$ と $\left(\boldsymbol{v}_{\jmath_{1}}, \boldsymbol{v}_{\jmath_{2}}\right)$

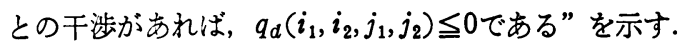

Fig. 4 に示すように, 稜 $\left(f_{i 1}, f_{\imath 2}\right)$ と $\left(v_{j_{1}}, v_{j_{2}}\right)$ が 干渉している場合,

$$
\begin{aligned}
\left|\boldsymbol{f}_{\imath_{1}} \cdot \boldsymbol{v}_{j_{1}}\right|: \boldsymbol{a} & =\left|\boldsymbol{f}_{\imath_{1}} \cdot \boldsymbol{v}_{j_{2}}\right|:(b+c) \\
\therefore \quad \frac{\left|\boldsymbol{f}_{\imath_{1}} \cdot \boldsymbol{v}_{j_{1}}\right|}{\left|\boldsymbol{f}_{\imath_{1}} \cdot \boldsymbol{v}_{j_{2}}\right|} & =\frac{\boldsymbol{a}}{(b+c)}
\end{aligned}
$$

となる。同様に,

$$
\begin{aligned}
& \left|\boldsymbol{f}_{\imath 2} \cdot \boldsymbol{v}_{j 2}\right|: c=\left|\boldsymbol{f}_{i 2} \cdot \boldsymbol{v}_{j 1}\right|:(a+b) \\
\therefore \quad & \frac{\left|\boldsymbol{f}_{\imath 2} \cdot \boldsymbol{v}_{j 2}\right|}{\left|\boldsymbol{f}_{\imath 2} \cdot \boldsymbol{v}_{j 1}\right|}=\frac{c}{(a+b)}
\end{aligned}
$$

である. 従って,

$$
\begin{aligned}
& \frac{\left|\boldsymbol{f}_{i_{1}} \cdot \boldsymbol{v}_{j_{1}}\right|}{\left|\boldsymbol{f}_{i_{1}} \cdot \boldsymbol{v}_{j_{2}}\right|} \times \frac{\left|\boldsymbol{f}_{i_{2}} \cdot \boldsymbol{v}_{j_{2}}\right|}{\left|\boldsymbol{f}_{i_{2}} \cdot \boldsymbol{v}_{j_{1}}\right|}=\frac{a \times c}{(a+b) \times(b+c)} \leqq 1 \\
& \therefore\left|f_{\imath_{1}} \cdot \boldsymbol{v}_{j 1}\right| \times\left|\boldsymbol{f}_{\imath_{2}} \cdot \boldsymbol{v}_{j 2}\right| \\
& -\left|\boldsymbol{f}_{i_{1}} \cdot \boldsymbol{v}_{j_{2}}\right| \times\left|\boldsymbol{f}_{i_{2}} \cdot \boldsymbol{v}_{j_{1}}\right| \leqq 0
\end{aligned}
$$

となる.ここで, 稜 $\left(\boldsymbol{v}_{j 1}, \boldsymbol{v}_{j 2}\right)$ は $\boldsymbol{f}_{i_{1}}, \boldsymbol{f}_{i 2}$ の両方と交 差しているので, $f_{\imath_{1}} \cdot v_{j 2}<0$ かつ $f_{\imath_{2}} \cdot v_{j 1}<0$ である.

これと（9-1）式より，明らかに上式は絶対值にしなくて も成立する. 従って $q_{d}\left(i_{1}, i_{2}, j_{1}, j_{2}\right) \leqq 0$ である.

以上の結果をまとめると，次の補題がいえる.

[補題]

$\Gamma(8)$ 式を満たす凸多面体の稜 $\left(f_{\imath 1}, f_{\imath 2}\right)$ に対し，(91)，(9-2）式を同時に満たす他方の凸多面体の稜（ $\boldsymbol{v}_{j 1}$, $\left.\boldsymbol{v}_{j 2}\right)$ のすべてが,

$$
q_{d}\left(i_{1}, i_{2}, j_{1}, j_{2}\right)>0
$$

を満たせば，稜どうしでの干渉はない」.

この補題を基にして, 稜どうしでの干渉をチェックす るためにつぎの関数を定義する.

$$
q_{e}\left(p_{1}, p_{2}\right)=\max _{i 1, i 2}\left\{\min _{j 1, j 2}\left\{q_{d}\left(i_{1}, i_{2}, j_{1}, j_{2}\right)\right\}\right\}
$$


（12）式を用いれば，凸多面体 $p_{1}$ と $p_{2}$ が稜どらしで 干涉しないための十分条件は，

$$
\max \left\{q_{e}\left(p_{1}, p_{2}\right), q_{e}\left(p_{2}, p_{1}\right)\right\}>0
$$

となる.ただし(12)式は，今までの議論から明らかなよ らに(8)式を満たす稜 $\left(f_{\imath 1}, f_{\imath 2}\right)$ が存在し，その稜に対 して(9-1)，(9-2)式を満たす稜 $\left(\boldsymbol{v}_{j 1}, \boldsymbol{v}_{j_{2}}\right)$ が存在する場 合にのみ意味を持つ.ただここでは十分条件を求めてい るので，条件を満たす棱が存在しない場合は，干涉があ るとして適当な負の值をとるとする.

\section{4 凸多面体どうしの干渉の関数表現}

これまでに定義した関数を用いると，次の定理が成り 立つ.

[定理]

「凸多面体 $p_{1}, p_{2}$ が干渉しないための必要十分条件は,

$$
q\left(p_{1}, p_{2}\right)=\max \left\{q_{f 12}, q_{f 21}, q_{e 12}, q_{\epsilon 21}\right\}>0
$$

である、ただし，

$$
\begin{aligned}
& q_{f 12}=q_{f}\left(p_{1}, p_{2}\right), q_{f 21}=q_{f}\left(p_{i}, p_{1}\right), \\
& q_{e 12}=q_{e}\left(p_{1}, p_{2}\right), q_{e 21}=q_{e}\left(p_{2}, p_{1}\right)
\end{aligned}
$$

である.」

[証明]

今までの議論によって十分性は明らかなので，必要性 のみを証明する.

凸多面体 $p_{1}$ と $p_{2}$ の距離 $d\left(p_{1}, p_{2}\right)$ を,

$d\left(p_{1}, p_{2}\right)=\min \left\{\left\|z_{1}-z_{2}\right\|: z_{1} \in P_{1}, z_{2} \in P_{2}\right\}$

と定義すると，干渉していない時 $d\left(p_{1}, p_{2}\right)>0$ である. その時, $d\left(p_{1}, p_{2}\right)$ を与える点 $z_{1}, z_{2}$ が凸多面体のどこ に存在するかによって分類すると，次の 6 通りになる。

(1)面上と面上. (2)面上と稜上. (3)面上と頂点.

(4)稜上と稜上. (5)稜上と頂点. (6)頂点と頂点.

そこで，結論の否定，すなわち “ $d\left(p_{1}, p_{2}\right)>0$ にもか かわらず, $q\left(p_{1}, p_{2}\right) \leqq 0$ となる $p_{1}, p_{2}$ が存在する”と仮 定して矛盾を導く.

まず，(1)，(2)，(3)の場合を考える．この時， $d\left(p_{1}, p_{2}\right)$ を与える面を $f_{i 0}$, 頂点（の内の一つ）を $v_{\text {jo }}$ とすると， 以下の関係が成り立つ。

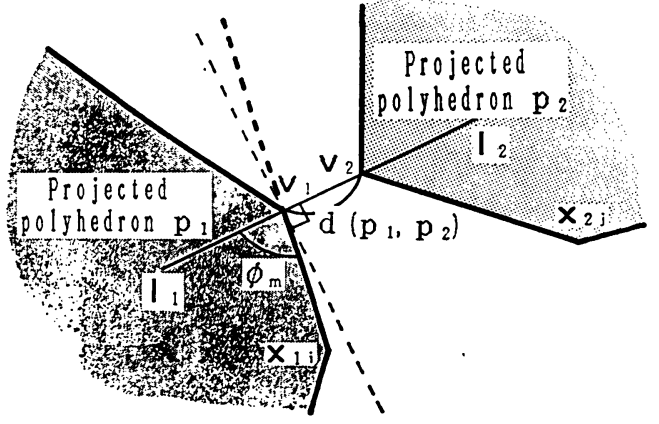

Fig. 5 Maximum angle $\phi_{m}$

$$
\begin{gathered}
d\left(p_{1}, p_{2}\right)=\boldsymbol{f}_{i 0} \cdot \boldsymbol{v}_{j 0}=\min _{j}\left\{\boldsymbol{f}_{\imath 0} \cdot \boldsymbol{v}_{j}\right\} \\
\leqq \max _{\imath}\left\{\min _{j}\left\{\boldsymbol{f}_{\imath} \cdot \boldsymbol{v}_{\jmath}\right\}\right\} \leqq q\left(p_{1}, p_{2}\right)
\end{gathered}
$$

これは，背理法の仮定に矛盾する.

次に(4)，(5)，(6)の場合であるが，(4)，(5)は66の特別な 場合として扱えるので，6の場合のみ証明する.

さて, 最も近い頂点の一方を $v_{1}$, 他方を $v_{2}$, それら を結んだ直線を $\overline{\boldsymbol{l}_{1} v_{1} v_{2} \boldsymbol{l}_{2}}$ とする. 頂点 $v_{1}$ からのびる稜 $\left(v_{1}, x_{1 \imath}\right)$ と直線 $\overline{l_{1} v_{1} v_{2} l_{2}}$ の作る角度 $\angle l_{1} v_{1} x_{1 \imath}$ および 稜 $\left(v_{2}, x_{2 j}\right)$ と $\overline{l_{1} v_{1} v_{2} l_{2}}$ の作る角度 $\angle l_{2} v_{2} x_{2 j}$ のうちで, 最大のものを $\phi_{m}\left(=\angle \boldsymbol{l}_{1} \boldsymbol{v}_{1} \boldsymbol{x}_{1 \imath}\right)$ とする. また， $\phi_{m}$ を 与える凸多面体を $p_{1}$, 他方を $p_{2}$ とする(Fig. 5). さら に, $\phi_{m}$ を与える稜 $\left(v_{1}, x_{1 \imath}\right)$ を構成する二面を $\boldsymbol{f}_{\imath_{1}}$, $\boldsymbol{f}_{\imath 2}$ とする.

今, $v_{1}$ と $v_{2}$ が最も近いので, $\phi_{m} \leqq \pi / 2$ である. も し $\phi_{m}>\pi / 2$ とすると, $p_{1}$ 内に $v_{1}$ よりも $v_{2}$ に近い点 が存在し， $v_{1}$ と $v_{2}$ が最も近いといら仮定に矛盾する. また，稜 $\left(\boldsymbol{v}_{1}, \boldsymbol{x}_{1 \imath}\right)$ を延長しても $p_{2}$ に交わらない。 し交わったとすると， $p_{2}$ には $\phi_{m}$ よりも大きい角度を もつ稜が存在し， $\phi_{m}$ の選び方に矛盾する. 従って $p_{2}$ のすべての頂点は，稜 $\left(v_{1}, x_{1 \imath}\right)$ を構成する二面 $\boldsymbol{f}_{\imath 1}, \boldsymbol{f}_{\imath 2}$ のどちらか一方の外側にあり (Fig. 6), 稜 $\left(\boldsymbol{f}_{\imath 1}, \boldsymbol{f}_{\imath 2}\right)(=$ 稜 $\left.\left(v_{1}, x_{1 \imath}\right)\right)$ は(8)式を満たす.

ここで, 次の二つの場合に分けて考える.

（フ） (9-1), (9-2)式を同時に満たす $p_{2}$ の稜 $\left(v_{\jmath_{1}}\right.$, $v_{j 2}$ )が存在しない場合.

（イ）そのような稜 $\left(\boldsymbol{v}_{j 1}, \boldsymbol{v}_{j 2}\right)$ が存在する場合.

（ア）の場合, (9-1), (9-2)式の幾何学的意味より, $q_{f 12}$ $>0$ となる.これは，背理法の仮定に矛盾する.

(イ)の場合, 稜 $\left(v_{j 1}, v_{j_{2}}\right)$ は Fig. 6 に示す通り $p_{1}$ を 稜 $\left(\boldsymbol{f}_{\imath_{1}}, \boldsymbol{f}_{\imath 2}\right)$ にそって投影した多角形に交わることはな く，すべて(11)式を満たす．従って,

$$
\min _{j_{1}, j_{2}}\left\{q_{d}\left(i_{1}, i_{2}, j_{1}, j_{2}\right)\right\}>0
$$

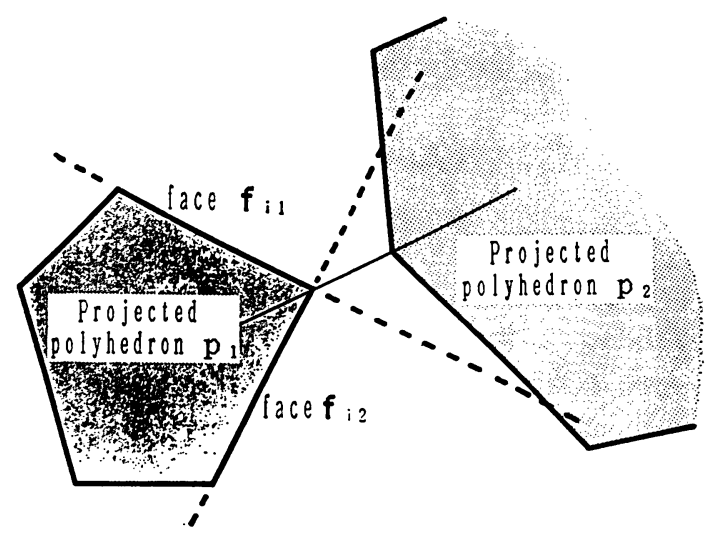

Fig. 6 Projection along the_edge which gives $\phi_{m}$ 
つまり, $q_{e 12}>0$ となり, 背理法の仮定に矛盾する.

どちらの場合も矛盾が生したので, 背理法により必要 性が示された。

<証明終り>

\section{4. 関節空間における干涉の関数表現}

\section{1 文次変換と関節変数}

前章の結果を多関節マニピュレータに適用する.リン クを表す凸多面体は，Denavit 等の表記法のを用いて各 リンク座標系 (Fig. 7) で表現する. ワールド座標系は 第 0 リンク座標系に一致させ, 障害物はワールド座標系 で表現する．この表記法を用いると，第 $k$ リンク座標系 での定点 $\boldsymbol{v}_{k}$ と, 第 $k-1$ リンク座標系で表記された同 し点 $\boldsymbol{v}_{k-1}$ との関係は,

$$
\boldsymbol{v}_{k-1}\left(\theta_{k}\right)=A_{k}\left(\theta_{k}\right) \boldsymbol{v}_{k}
$$

となることが知られている.ここで， $\theta_{k}$ は第 $k$ 関節の 関節变数であり, $A_{k}\left(\theta_{k}\right)$ は, $4 \times 4$ の变換行列である. また，第 $k$ リンク座標系での定平面 $\boldsymbol{f}_{k}$ 之，第 $k-1$ リン ク座標系で表記された同し平面 $\boldsymbol{f}_{k-1}$ との関保は,

$$
\boldsymbol{f}_{k-1}\left(\theta_{k}\right)=\boldsymbol{f}_{k} A_{k}^{-1}\left(\theta_{k}\right)
$$

となる.

これらの関係を用いると，第 $k$ リンク座標系での定点 $\boldsymbol{v}_{k}$ 及び定平面 $\boldsymbol{f}_{k}$ は, ワールド座標系（第 0 リンク座標 系) では,

$$
\begin{aligned}
& v_{0}\left(\theta_{1}, \cdots, \theta_{k}\right)=A_{1}\left(\theta_{1}\right) A_{2}\left(\theta_{2}\right) \cdots A_{k}\left(\theta_{k}\right) v_{k} \\
& f_{0}\left(\theta_{1}, \cdots, \theta_{k}\right)=f_{k} A_{k}^{-1}\left(\theta_{k}\right) A_{k-1}^{-1}\left(\theta_{k-1}\right) \cdots A_{1}^{-1}\left(\theta_{1}\right)
\end{aligned}
$$

のように, ベクトル $\left(\theta_{1}, \cdots, \theta_{k}\right)$ の関数で表される.

\section{2 関節空間における干涉の関数表現}

3 章で定義した関数 q を, 関節変数べクトル $\theta=\left(\theta_{1}\right.$, $\left.\theta_{2}, \cdots, \theta_{n}\right)$ の関数に変換すれば，それが関節空間におけ る干渉チェック関数になる.

今, 第 $m$ 障害物 $o_{m}$ と第 $k$ リンク $l_{k}$ との干渉を考え る. まず, $l_{k}$ の頂点をワールド座標系へ変換し， $o_{m}$ と 面との内積を計算すると,

$$
\begin{aligned}
& {\left[\begin{array}{c}
\boldsymbol{f}_{1} \\
\boldsymbol{f}_{2} \\
\vdots \\
\boldsymbol{f}_{f m}
\end{array}\right] A_{1}\left(\theta_{1}\right) \cdots A_{k}\left(\theta_{k}\right)\left(\boldsymbol{v}_{1}, \boldsymbol{v}_{2}, \cdots, \boldsymbol{v}_{v k}\right) } \\
= & {\left[g_{i j}(\boldsymbol{\theta})\right] }
\end{aligned}
$$

となる，あとは，(7-1), (12)式の定義に従い,

$$
q_{f}\left(o_{m}, l_{k}\right), q_{e}\left(o_{m}, l_{k}\right)
$$

を計算する。

同様に， $l_{k}$ の面をワールド座標系へ変換し， $o_{m}$ の頂 点と内積をとった結果に対しても, $q_{f}\left(l_{k}, o_{m}\right), q_{e}\left(l_{k}\right.$, $\boldsymbol{o}_{m}$ ）を計算する. そして,

$$
q_{m k}(\boldsymbol{\theta})=q\left(\boldsymbol{o}_{m}, l_{k}\right)
$$

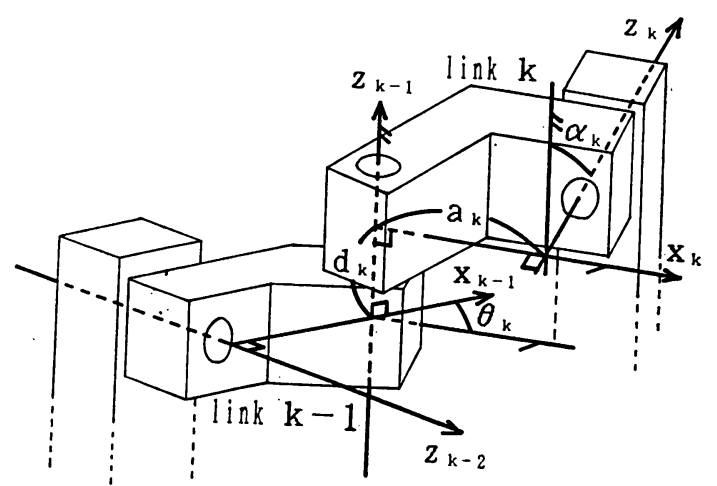

Fig. 7 Link parameters and coordinate axes definitions

とすれば, $o_{m}$ と $l_{k}$ との干渉を表す関数を関節変数べク トルの関数に変換したことになる.

以上の事を，すべてのリンクとすべての障害物につい て行えばよく, 求める関数 $q(\boldsymbol{\theta})$ は,

$$
q(\boldsymbol{\theta})=\min _{k=1 \sim n, m=1 \sim M}\left\{q_{m k}(\boldsymbol{\theta})\right\}
$$

となる.ただし， $n$ はリンク数，Mは障害物数である.

\section{5.おわりに}

本方法の特徵は, 障害物やマニピュレータ・リンクを 凸多面体またはその組合せで表現し，その干渉の必要十 分条件を比較的単純な関数を用いて表現したことにある。 また, 点と平面の位置関係のみから干涉チェック関数を 導いているので, Denavit 等の表記法を直接使え, 一般 の多関節型マニピュレータに適用できる.

また，紙面の都合上省略したが， $q(\boldsymbol{\theta})$ の $\theta_{\imath}(i=1,2$, ‥n）による偏微分は, 頂点と面, 稜と稜の組合せが, $\min , \max$ によって切り替わる所以外で（数学的にはほ とんどいたる所で）可能である．またその計算は，変換 行列 $A_{i}\left(\theta_{i}\right)$ を, 成分の入れ換えを行った行列 $A_{i}{ }^{\prime}\left(\theta_{i}\right)$ に換えるだけで良く，非常に容易である．また， $\boldsymbol{\theta}=\boldsymbol{\theta}$ (t) として経路を与えれば, $t$ の必要な領域 $R$ で $\min _{t \in R} q$ $(\theta(t))>0$ となるように $\theta(t)$ を計画すればよい. その 一手法として, 非線形計画法が使用でき, 障害物回避動 作を計画できる.ささら，表現が完全だから，関節空間 を自由領域と禁止領域に分割近似する場合にも被近似関 数として使用できる.

最後に，本研究をすすめるにあたり御討議いたたいた 細江繁幸助教授, 菅沼義昇助手, ならびに研究室一同に 感謝の意を表する.

\section{参考文 献}

1）尾崎, “マニピュレータの障害物回避”, 日本ロボット学 会誌, Vol.2, No.6, pp.76-82, 1984

2) Tomas Lozano-Perez, "Spatial Planning : A Config. 
uration Space Approach", IEEE, Trans. Computers, Volc-32, No.2, Feb.pp. 26-38, 1983

3）小沢他, “オフラインロボット教示における高速干涉チ ニックの一方式”, 日本ロボット学会誌, Vol 4, No.2, pp. 79-88, 1986

4) J. W. Boyse, "Interference Detection Among Solids and Surfaces", Communication of the ACM, Vol.22 No. 1, pp. 3-9, 1979

5）尾崎他，ママニピニレータの占有空間を考虑した障害物 回避動作の決定法”, 計測自動制御学会論文集, Vol 18, No.9, pp.72-79, 1982
6）長谷川，“自由空間分類表 現法によるマニピュレータの 衝突回避動作の計画”, 計測自動制御学会論文集, Vol 22, No. 6, pp. 20-26, 1986

7）重松他，“3-D形状モデル間干涉問題の一解法”, 精密機 械, Vol.49, No.11, pp. 89-94, 1983

8）湯浅他, “多関節マニピニレータの動作計画”, 第 15 回 制御理論シンポジウム資料，第 12 回システムシンポシ ウム講演論文集, pp. 131-134, 昭和 61 年 6 月

9) Richard P.Paul, (吉川恒夫訳) “ロボット・マニピュ レーダ, コロナ社, 1984

\title{
Interference Detection among Manipulator Links and Obstacles for Planning Collision-free Movement of a Manipulator*
}

\section{Hideo YUASA** Masami ITO**}

\begin{abstract}
When a collision-free movement of a manipulator is planned, it is necessory to detect the interference among manipulator links and obstacles. Until now, the detection has been simplified by adding various conditions mainly. But this paper proposes an interference detection method which is relatively general and is simple to calculate. Manipulator links and obstacles are approximated by convex polyhedra or these combinations. And a necessory and sufficient condition of interference between two convex polyhedra is expressed by using a relatively simple function which uses only a relation of these faces and vertices.

And this function can be transformed easily to the one whose argument is a joint vector by using the notation of Denavit et al. Then, this method is well applied to planning collision-free movement of a manipulator because of detecting interference also in the joint space of all joint vectors.
\end{abstract}

Key words : manipulator, interference detection collision free, joint-space, convex polyhedron

* Received December 18 th, 1986

** Dept. of Information Eng. Faculty of Eng. Nagoya Univ. 